\title{
MATHEMATICAL CHARACTERISTICS OF THE CHILDREN THAT SHOWN ABOVE/BELOW AVERAGE SUCCESS AT THE MATHEMATICAL EDUCATION
}

\begin{abstract}
Department of mathematics, Faculty of Science, University of Tuzla, Bosnia and Herzegovina Elementary school "Turbe "in Travnik, Bosnia and Herzegovina

Faculty od Eduacation, University of Travnik, Bosnia and Herzegovina

Faculty od Education, University of Travnik, Bosnia and Herzegovina
\end{abstract}

\author{
Received: 2019/1/10
}

Accepted: 2019/3/29

\begin{abstract}
In this study, we analyzed the emotional and conative characteristics of fourth grade students of elementary school as follows: motivation for learning math, situational interest in learning mathematics during teaching, mathematics anxiety, self-esteem in relation to academic achievement and attributions of success and failure in mathematics. In a sample of 200 students and 20 teachers were analyzed emotional and conative characteristics capable of above-average and below average in math-age students. The study used the descriptive method, a questionnaire and a test. The research results are presented graphically and in tabular form with an explanation and discussion. In the conclusion are set the directions which should further improve this insufficiently studied area.
\end{abstract}

Keywords: mathematics, giftedness, emotional and conative characteristics, teaching, teacher, student

\section{INTRODUCTION}

By mentioning above average most of the people think about the high inteligence children, or the children that are above average at arts, physical activities and similar. Development of above averegness is a consequence of interaction between inside factors (cognitive and coactive)and outside social factors. In other words high inteligence children undubtly posess potential for succes at various activities, but will this factor develop, and will the child make above average sucess at one or more of thi areas depend on other inner and outer factors. Most mentioned inner factor is motivation, self anxiety, system of values, interest, controle place, temperament, and similar (Joswig, 1994). Modern reasearch proves that this factors are responsible not only for differences at succes between above average, and below average children, but also for differences in the set of above average ones.

\section{${ }^{1}$ Correspondence to:}

Sead Rešić, Department of Mathematics, Faculty of Science, University of Tuzla, Bosnia and Herzegovina

Univerzitetska 4, 75000 Tuzla, Bosnia and Herzegovina

Phone:+387 61101230

E-mail: sresic@hotmail.com 
We usually conclude that the children that posess above average inteligence are ment to be high graded at school and out of it. But the reasearches from psicology of motivation and the reasearches on the sets of high inteligence children show distinct results (Cudina-Obradovic, 1991). High inteligence children undubtly posess potential for succeess $i$ various activities.But will this potential develop and will the child make above average results in certain areas depends on distinct iner and outer factors. The most important outer factors are activities by enviroment(primary from family and school), which means will the child get a chance to show what he(she) can do. The most mentioned inner factors are motivation, self anxiety, persistence, construction of values, interest, place of controle, temperament and similar (Joswig, 1994). The reasearch shows that this factors are responsible not only for the differences between success at above average and belowe average children, but also for the differences between the members of the set of above averages. Specific set inside the set of above average make are the children with the gift for mathematics. This are children that beside above average general inteligence make above average results at the tests of mathematical abilities. This are the children which during the socialiyation process develop precise interest for mathematics, and realised it using a lep of above average abilities, and probably sutible effects of enviroment. All of this resulted with high succes of solving mathematical problems, especially those which requires high rate of cognitive functioning. It is well known that the children that the children due to intelectual abilities can be separated even at pre school age, but inquested is at what age is possible to see the difference between the children with and without gift, observing their conactive characteristics? In other words one of the fundamental questions at this area is when the abilities of above average children become visible? Are they visible already at pre school and younger scoll age or they become obvious after this age? Related with this inquested is are this abilities visible at the same areas at the same age? Since the most of reasearch at mathematics area observes post age childrens, at this reasearch we want to check is there a difference at ten years old mathematics above average students and their avarege colleges at some emotional an connactive abilities. Generally for identification above average children we use following sources of information: measuring scale and lists for checking, distinct kinds of standardized tests, and teachers remark.Since the most of reasearch observes the older children, at this reasearch wi will check if ten years old above average students differ from their belowe average colegues at some emotional and conactive abilities. The topic of this work will be "Mathematical characteristics of the children that shows above/belowe average succes at the mathematical education".

\section{Visible shapes of gift}

Besides distinct understanding and definitions of gift inportant are are the names which sometimes denote clear differences at the term of gift. Here wi will explain their meaning in the light of previous analysis of giftnes.

A child with a gift at the behaviour shows the signs of ability of creator. There are a lot of signs, and often are visible at very young age, mostly show the presence of high intelectual abilities (advantage at studying, memory, humor sense, describing sources ond conecting it to consequaences) or specific abilities:music, arts, psycomotoric or social. Usualy from noticing the signs of gift to its manifest at productional-creative shape 10-15 years should pass in intensive educational process and training.

Miracle of child is a special case of a child with a gift. This manifest is explained by »decelagea«, which means unequal development of distinct abilities of the child: it is mostly manifested at development and results at one area, while the other aspects of development have a normal tempo. Such pshyhical development has no negative consequaences, while unequal, early or fasten phisical development is mostly a sign of some kind of desease conditions. Any single case of "vunderkinda« is a result of very rear kind of enviroment action combination which means, nice conection of specialised inharited dispositionswith specific especially accented applicability and sensuability of enviroment. According to the modern understanding of a gift "child miracle" is not a miracle but only extrem, most visible case of the actions at development of any gifted child.: intensive and selected education very developed specific abilities (examples: J. S. Mills learned classical Greece when three year ol;15-year old has a dozen of patents; 9-year old completly musicly educated;student gives a computer lessons to the teachers, etc.)

Idiot-wise men are also the form of unbalanced and unequal very intensive development of some specific ability. Already as a children they show very specialised talents, as an example incredible memory for numbers, dates, ability of fantastic calculations in their head, or memorizing complicated music contests. They mostly show very developed one very narrow ability, while the others abilities are mostly retarded. 
American psychologist Howard Gardner (1983) claims that idiot wise men are also child miracles, proof that there are spesialised neurological areas in the brain which are responsible for certain kind of ability (examples: retard child Obadia is by itself when six years old learned how to add, subtract, multiply and divide; George with six years could exactly say the day at the week of far away passed year learning the characteristics of eternal calendar; 11-year old memorizes endles series of numbers.)

Genius is a term that inside the term of gift has two meanings. Both meanings are connected with the understanding of high level of ability.

Inside the psycometric definition of the term "genial« meaning on the people havig an inteligence coefficient higher tha 160. Nowdays the term of genius at this statistic-psyhometric sense is abounded and the term »extremely gifted «, »extreamly high gifted «. The other meaning of the term genius also atributes to the persons who during the life time created a huge corpus of creations which have valuable effect to the human mind and a situation. This is understanding of the term genius which coincides with productive-creative giftness with the accent of the presence especially huge development of motivational-creative completnes of ability. A talent is a term which inside the term of gift has especially undefined use. One of the meaning of the talent is which is nowdays called $\gg$ manifested giftness «, for the difference of potential giftnes which is denoted only with the term "giftness «. In the other meaning "talent $"$ is rated as a bit lawer rated degree, and "giftness « on a higher degree of intelectual giftness. The newest understanding a term talent is in correlation with multiple definition of giftness:while high intelectual abilities represent base of general giftness, till that the abilities which ensure high success in specific areas (arts, sports, social) - base of specific gift or talent. Besides the parents during the development of gift an inportant roll play the educators, teachers, professors, and general characteristcs of educational place. While considering the action of teacher in the gift development we should make a difference between the meaning of the word teacher:

1. Teacher as a creator of an atmosfere sutible for the development of a gift,

2. Teacher-parrent,

3. Teacher-educator of students with gift,

4. Teacher - mentor.

\section{Pedagogical bases of the work with mathematics gifted students}

Quality of work with gifted students at mathematics area depends not only on good knowledge of psyhological aspects of work with young mathematicians but also on adoptable use of advence knowledge of modern pedagogical sciences, certanly quality of a teacher besides very good knowledge of the area he is involved in also includes didactic-metodic ability.

Basic componentsof good work with gifted students Initial base for the work with young gifted mathematicians certanly constructs knowing and analysis of all components which follow god planned work with gifted students.

Analysing and combining reasearches of various reasearcers Šefket Arslanagić in his works tells about 16 components which create a good work with gifted students: ${ }^{2}$

1. Quality of mathematical contestconsiders precise planned topics of work and their inner logical and mathematical conection. Well planned program of work guarantees continuity of realisation of work and expected effects. Mathematical contests are not only simple spreading or deeping school program but also measured materials which contain neccesarily enlarged level, and are directed to adopting neccesary knowledge and forming exactly planned logical functions.

2. Right pedagogical accessis necesarry, since any improvization would be negation of the work with students with gift. Forms and methods of work with students with gift have to be an object of careful observation and as distinct as possible. Work with students with gift is interactive precess during which students effect their teachers.

3. Teacher abilityas one of the most inportant factors at the work withstudents with mathematics gift. Teacher plans and makes a program for work, prepairs materials, recomandes litterature, organizes a lesson, identifies students with gift, motivates and leads. He is the one who has to have excelent knowledge of mathematical contents, but also a good metodist, pritty instructed in pedagogical and psyhological base of education and additional work with the students with gift.

\footnotetext{
${ }^{2} \mathrm{dr}$ Sefket Arsanagic: Aspects of math teaching for gifted students, Association of mathematicians BiH, Sarajevo, 2001.
} 
4. Directing to the problem solving and applicationis one of the most important components of the work with gifted mathematicians. Students shold be taught to get knowledge, to solve a problems, and then those explorations and knowledge apply in practice.

5. Good comunication skill is necesarry for mathematics learning. From gifted students expectacions are to read and write, speak and think as mathematicians. Condition for that is good comunication on the relation teacher-student and student-student. Modern comunicational tools are good help for the work and making advantage with gifted students for succesful comunication.

6. Directing to higher levels of thinking is an important mark at the work with gifted students, and is reflected at constant attempts to direct the work deeper then solving the problem towards new explorations and results.

7. Skill of teaching and work adaptionare an inportant factore of good work with young mathematicians. Only gift has no great chance if an extraordinary intelectual potential is not followed by sutible working abilities. At the work with gifted we must insist on reading, making data bases, and good organization of studying and responsible relation to the work that has to be done.

8. Individual differences between the students which are identified as gifted is certain. Students need a help to find theirself at the world of great mathematical secrets, also as in daily enviroment in which people practice arts, sports and other activities.

9. Initialasing of creativity is an inportant characteristic of god work with gifted students. All the students have to get a chance for creational expression. Gifted students have to be constantly forced to show original solutions, to give an ideas, to explore and to make experiments.

10.Helping tools for studying, and before all working materials, mathematical magazines and litterature, humans as a living helpful tools for studying are necesarry followers of the good planned work with gifted. To this group of tools should be added printed medias, radioand television as well as the other audio-visual and comunicational tools.

11.Planning and development and good coordination in the borders of all working program with gifted students is necesarry. Program has to be evolutional and directed towards unexplored potentials of the gifted students. Process of planning should be set up flexibly, so in the case of need there could be made changes and aditives to the plan.

12.Integration of contents should contain inner corelation as wel at mathematical contents but also the contents of other lesons. This corelation has to be manifested at the work with gifted at mathematics as well as the other teaching subjects.

13.Mark of realization working plan with gifted dinamicly observed is constant work.Following the student development and eficiency of predicted procedures leads to the faster students upgrade. That is the reason the methods of following should be various.

14. Concern for studentsis necesarry, and teachers, realisers of the program for gifted had to be involved at single needs and the problems of gifted students. Bad thing is if the gifted are directed only to mathematics and if the presence on the other programs is forbidden, because the program for gifted should also protect them from social isolation.

15.Mobility and flexibility of the program contains certain comotion necesarry for moving any of gifted students in or out planned procedures and activities.

\section{Traditional school versus active school}

Tha aim of topic „traditional school versus active school“ is a confrontation of those two concepts (which in reality certanly is not presented in that measure), through presenting characteristics of one and other school and analysis of the school spirit which slowly should be abounded, and school spirit towards we should move, spirit that is more sutible and gives better chances to the gifted students.

Traditionalschool works with already prepared defined plans and programs and the aim of teaching activities is adopting the program. Basic method of education is lesson (verbal presenting of knowledge) with temporary use of teaching tools. Student is mostly passive listener and has to memorise, understand, and reproduce given subject. Marking, no matter verbal or by paper exam is constructed by checking the given subject is adopted. Motivs for studying are mostly of outer nature (mark, honorable mention, reward, punishment,...). At traditional school child is observed as a student, which means a person who would with understanding at as more as possible manner repeats subject he has heard.Active school is more focused to young man who is treated as a complete personality, whose intelectual needs should be engaged at teaching process as more as possble. Active school is based on educational standards which are used to construct orientational plans and programs of work. Such access considers the part of lesson which is settled flexible and varies depending of students interest, and studying is attached to the students interests. Motivation for studying is personal (inner). 
At the lesson dominate active methods of studying which are based on work and intelectual engagement of the students at explorational activities. The aim of active school is not only adopting lesson program but allsided development of personality, and individuality of the student.

Analysing explored characteristics we can conclude that for the work with mathematics gifted students is more acceptable active school and that the concept of work with mathematical talents should be directed to:

- respecting the personality of gifted;

- considering age and intelectual characteristics of gifted;

- spreading repertoars of educational methods for the work with gifted;

- motivation of talented;

- forsing former intelectual development of gifted.

At the mathematics education, especially at the work with gifted at this area this metod is necesarry, since by using litterature no matter at home or at the library or at internet is crucial for qualitative advanced knowledge adopt. Students get the possibility by using textual materials to make progress individually by dinamics conditioned by their own free time and prepareness to use that time rationally and for faster progress at the mathematics area. Teachers-specialists for the work with talented mathematicians are created and educated. That is why is necesarry to have precise strategy of their identification, following and professional development. By organised work on special didactic-metodic, and metodologic education of those people it is necesarry constantly make a progress at the work with mathematics gifted itself. Teachers that work with gifted students very often are regruted from the set of previous succesful competitors.

\section{METHODS}

\section{Aim of reasearch}

Aim of reasearch is to confront mathematics above average and belowe average students of the fourth grade of primary according to the following conactive and emotional charasteristics: motivation for mathematics studying, interest for studying during the lesson, mathematical anxiety, selfrespect related with promotion at school and atribute of success and unsuccess at mathematics. Group of mathematical above average students will be identified at the base of teacher judgement, as a problem at the test of mathematics knowledge. The other group will be constructed by the students of an average abilities with no mathematical above average children.

\section{Problems of reasearch}

- Confirm if the mathematical above average children have a greater motivation for studying then below average students.

- Confirm if the mathematical above average students have greater selfrespect then the below average students.

- Confirm if the mathematical above average students accept more easily unsuccess then the below average students.

\section{Main hypotesis}

Check if ten years old mathematical above average differ by some conactive and emotional abilities from their below average colegues.

Subhypotesis:

- We suppose there is a difference at conaktive characteristics between above average and belowe average students.

- We suppose there is a difference at emotional characteristicsbetween above average and belowe average students.

- We suppose that mathematics above average students have a greater motivation for studying then their below average colegues.

\section{Sample of reasearch}

In the process of choosing samples we will apply sutible action-testing of students which ensures that the sample is sufficiently large and homogenius as well as representative.

Students above average wil mark the teachers from the scale PROFNAD (Koren, 1989). On the fundament of high results at numerical test will be chosen the students which are quested by the test of knowledge from mathematics, constructed specially for this purpose. And finally at the group of above average the students with the best knowledge test results will be inserted. Criterion for choosing the children in other group will be those which at numerical test didnt show succes more distanced from an average more than one standard deviation in the direction of better results.Population at this reasearch are the students of primary school of the Travnik area, as a sample we have primary school fourth graders of primary school "Turbe“. 


\section{Methods and reasearch technics}

At the reasearch we will use analytic-descriptive method, methof of theoretical analysis (studying of school documentatiton, which means student success). Reasearch technics which wil be used at this work are: testing, question mark for students, and scaling as wel as statistical data observation.

\section{Calendars and a way of reasearch}

Reasearch is done in the second halfyear of 2014/15 at primary school „Turbe“. We have visited the school talked to director and pedagogist and teachers of the school so the way of executing the program could be explained, meaning students testing, and inportance of the reasearch itself.

\section{RESULTS}

In this chapter are analised and interpreted the results we have got from reasearch of given topic. The ways of shown results are table grafic and textualy in the way of explanation. The reasearch is done in the period 1-13 march 2015 year. Reasearch includes 220 members, 200 of them are students and 20 teachers. At all the number of members 97 were man and 103 women. Students from choosen sample fulfilled an ankete which tested giftnes of the students, as well as emotional and conactive characteristics. On the following two graphs are shown classification of total number of tested students on the base of an average succes at the end of the first halfyear, as well as on the basis of an average mathematics mark.

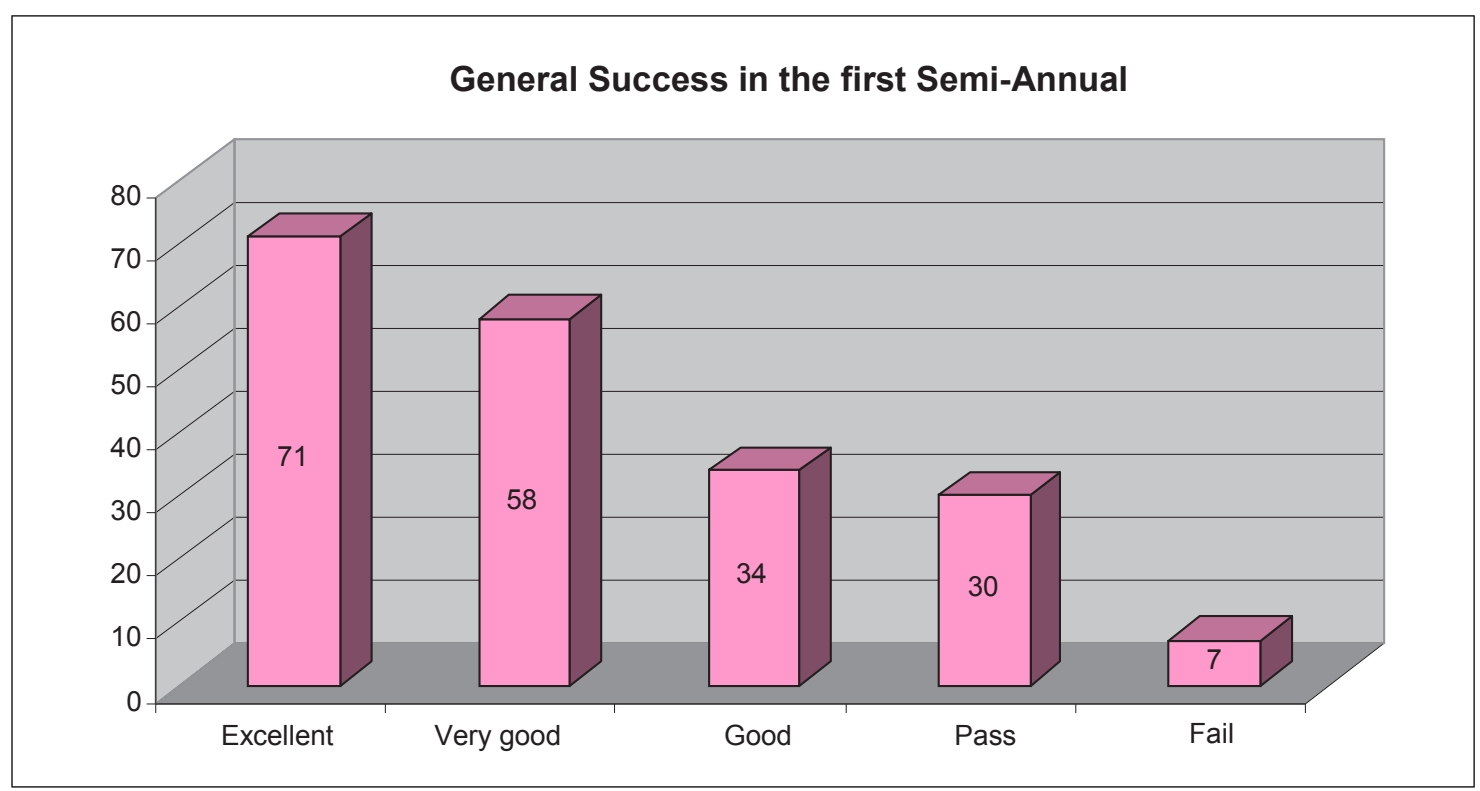

Graph 1. Classification of students on the base of success at the first halfyear

\section{Number of Students with a final Grade from Math at the End of the first Semi-Annual}

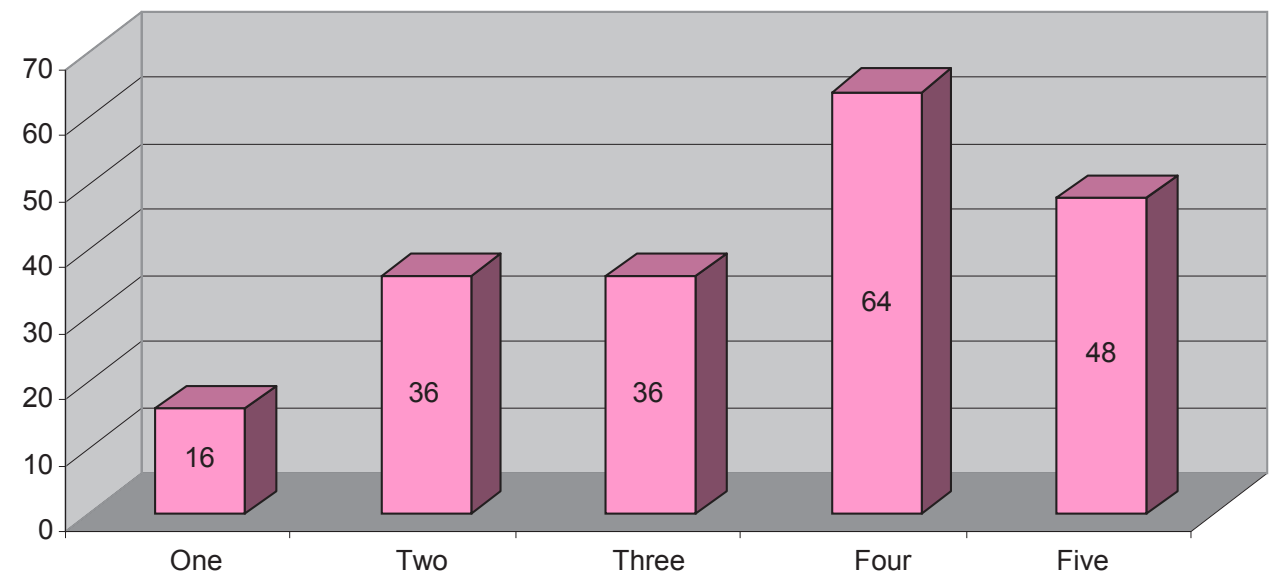

Graph 2. Classificationof students on the base of mathematics mark 
Analysing data we have got from previous graphic number of students at mentioned two schools which ended the first halfyear with grade 5 is 71 or $35.5 \%$ of total number of students in research, grade 4 get 58 students or $29 \%$, grade 3 got 34 students or $17 \%$, grade 2 got 30 students or $15 \%$, and 7 of the students at the end got a grade 1 or $3.5 \%$ of total number of students at research. An average general mark of the chosen sample at the end of the first half year was 3.804. Analysing the data from the other graphic number of students which ended firs halfyear with grade 5 is 48 or $24 \%$, mark 4 has got 64 or $32 \%$ students, grade 3 , 36 or $18 \%$ students, grade 2,36 or $18 \%$ of students and 16 students endeed first halfyear with grade 1 or $8 \%$ of total number of students. An average mathematics mark of the chosen sample at the end of the first halyear was 3.64. We can conclude that the average mathematics mark is lower then the general mark on the chosen sample for $4 \%$. On the base of filled ankete and marking correct answers students from mathematics as on the base teacher judgement students are divided into two groups:above average able and belowe average able for mathematics. Criteria for choosing the children that will be at above average group is is the result they showed at numerical test, the results that are distante for a half of standard deviation from the average mark in the direction of better results. Above average for mathematics is 69 students or $34.5 \%$ from the chosen sample, while below average students number is 131 or $65.5 \%$ of the sample. Aproximetly is the same number of boys and girls at the shown structures, so we can conclude that the genre is not effectible to it. Relation of above average and below average for mathematics is shown on the following graph.

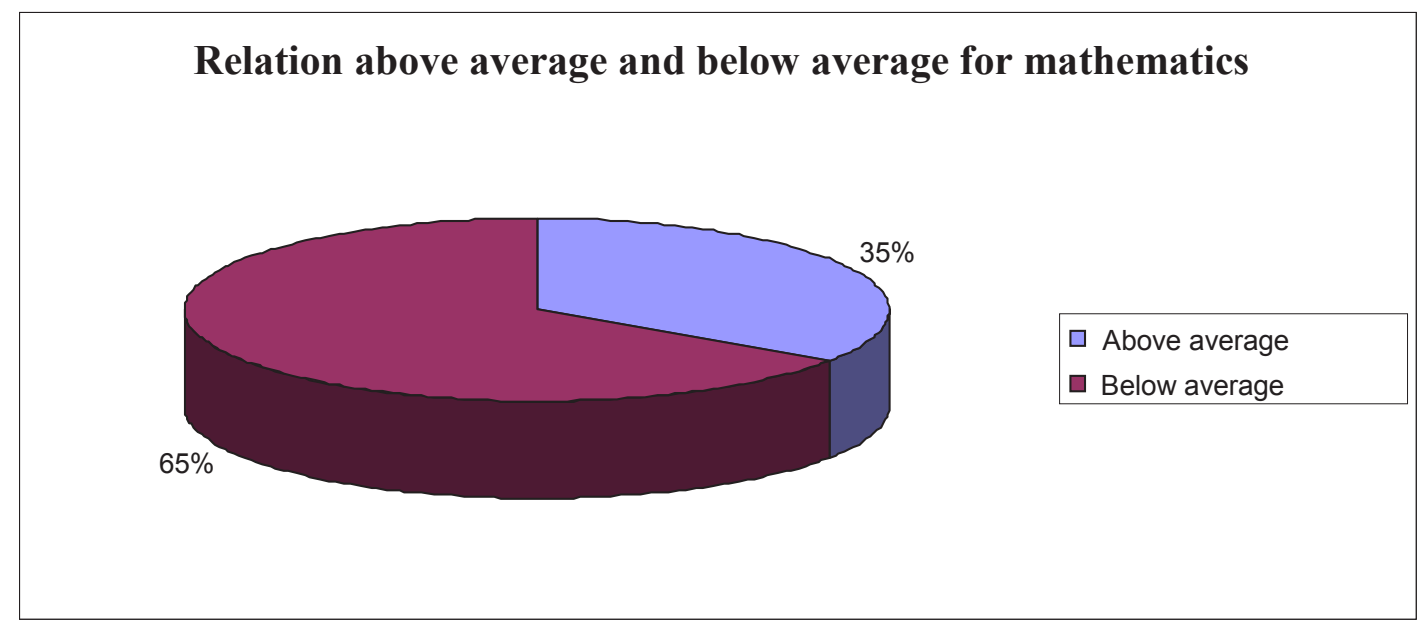

Graph 3. Relation above average and below average for mathematics

\section{Motivation for mathematics studying}

Motivation is an inportant factor of succesful studying. Motivated student makes much beter progress at studying then the student which is not motivated. There are various motives which force students to study mathematics, like, interest in mathematics, desire to show personal value, desire for constant spreading of mathematical knowledge, promissed reward or punishment, desire to get a beter mark, wish to get to the solution of the certain problem, cocesnes to about need of mathematics studying ,need to help the others, good teacher that motivates the students to learn the mathematics, etc.
At the chosen sample we confronted motivation for mathematics studying of above average and belowe average students of the fourth grade. Special anket is prepared for teachers who graded from 1 to 5 certain claims related to motivation above average and the motivation of belowe average students Marking total motivation of the students for mathematics studying at above average group of students following results are got. The mark is an important motiv for above average, but besides the marq equaly or even more motivating are teachers mentions, desire for spreading mathematical knowledge, desire to show personal value. In the next tables are the answers of teachers. 
Table 1. Motivation of above averages for mathematics

\begin{tabular}{|c|c|c|c|c|}
\hline \multicolumn{5}{|c|}{ ABOVE AVERAGE FOR MATHEMATICS } \\
\hline \multicolumn{5}{|c|}{ Need to help the others is an inportant motiv } \\
\hline \multirow[t]{2}{*}{1} & 2 & 3 & 4 & 5 \\
\hline & & 4 & 12 & 3 \\
\hline \multicolumn{5}{|c|}{ Better mark is an inportant motiv } \\
\hline \multirow[t]{2}{*}{1} & 2 & 3 & 4 & 5 \\
\hline & & 4 & 10 & 6 \\
\hline \multicolumn{5}{|c|}{ Teachers mentions are inportant motiv } \\
\hline \multirow[t]{2}{*}{1} & 2 & 3 & 4 & 5 \\
\hline & & 2 & 7 & 11 \\
\hline \multicolumn{5}{|c|}{ Desire to show own personality is an inportant motiv } \\
\hline \multirow[t]{2}{*}{1} & 2 & 3 & 4 & 5 \\
\hline & & 5 & 6 & 9 \\
\hline \multicolumn{5}{|c|}{ Desire for spreding mathematical knowledge is an inportant motiv } \\
\hline \multirow[t]{2}{*}{1} & 2 & 3 & 4 & 5 \\
\hline & & 6 & 6 & 8 \\
\hline \multicolumn{5}{|c|}{ Total mark of motivating for mathematics } \\
\hline 1 & 2 & 3 & 4 & 5 \\
\hline & & 1 & 9 & 10 \\
\hline
\end{tabular}

Table 2. Motivation below average for mathematics

\begin{tabular}{|c|c|c|c|c|}
\hline \multicolumn{5}{|c|}{ BELOW AVERAGE FOR MATHEMATICS } \\
\hline \multicolumn{5}{|c|}{ Need to help the others is an inportant motiv } \\
\hline 1 & 2 & 3 & 4 & 5 \\
\hline 4 & 7 & 9 & & \\
\hline \multicolumn{5}{|c|}{ Better mark is an inportant motiv } \\
\hline \multirow[t]{2}{*}{1} & 2 & 3 & 4 & 5 \\
\hline & & 6 & 9 & 5 \\
\hline \multicolumn{5}{|c|}{ Teachers mentions are inportant motiv } \\
\hline 1 & 2 & 3 & 4 & 5 \\
\hline 3 & 8 & 7 & 2 & \\
\hline \multicolumn{5}{|c|}{ Desire to show own personality is an inportant motiv } \\
\hline 1 & 2 & 3 & 4 & 5 \\
\hline 4 & 7 & 7 & 3 & \\
\hline \multicolumn{5}{|c|}{ Desire for spreding mathematical knowledge is an inportant motiv } \\
\hline 1 & 2 & 3 & 4 & 5 \\
\hline 4 & 6 & 8 & 2 & \\
\hline \multicolumn{5}{|c|}{ Total mark of motivating for mathematics } \\
\hline 1 & 2 & 3 & 4 & 5 \\
\hline & 5 & 13 & 2 & \\
\hline
\end{tabular}

On the base of visible results we can conclude there is a huge difference in motivation for studying mathematics of above average and below average mathematicians. General mark of above average mathematicians is 4.45 , while the same one of below average mathematicians is 2.85 . This confirmes the hypotesis that above average students have a greater motivation for studying mathematics then the below average.

On the question Is a good teacher good motiv for studying mathematics?

Above average students gave the answer shown on following grafic Graph 4., while the answers of below average students are shown on Graph 5. 
Is a good teacher a good motive for learning mathematics

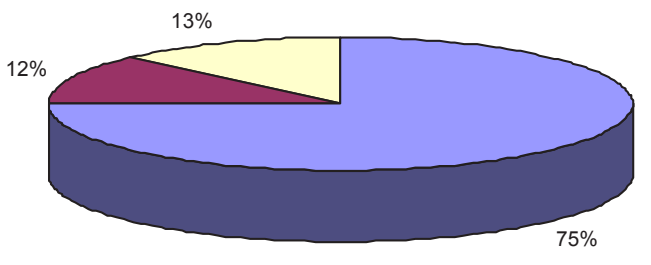

Graph 4. Answers of above average students

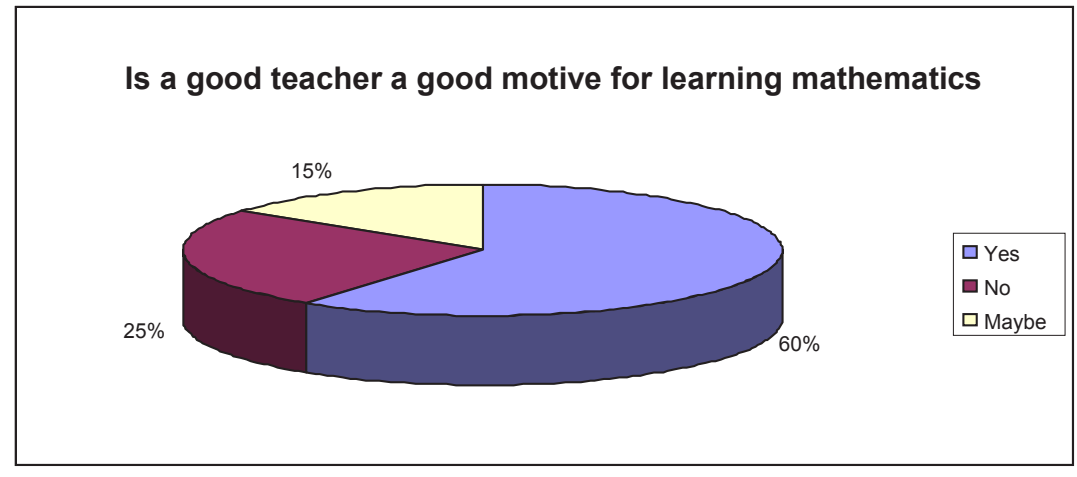

Graph 5. Answers of below average students

Using shown results we can see that good teacher can affect the students to learn mathematics. Obviously is also there is a difference between above average and below average students. Student needs to be effected to study because of their own progress, and preparation for life. Student must not be ,foreign body“in the process of education but has to be integrated in that process. Has to be involved in it from programming across showing and checking all to the giving value to the work. Student should be motivated to study such that outer effects are demanded by inner. On the base of collected data from our ankete we conclude that the problem for high grade mostly motivates the student for studying mathematics. Obviously it comes out from nowdays social reality, and that the psycosocial motivs are the greatest factors studying and work, which tells also about educational aspect motivation of the student. Motivation of the student is socialy conditioned, and motivating depends on living of educational contents. Motivation of the student depends on position and tretman of a men at given social time and its contradictionaries. Nowdays at our area knowledge is less then valuable, but social position and the ability for getting material things is very valuable. Needs are to get a position, to be rich and powerful. Knowledge is not necessary at this area yet, at least it is not visible and sesible. Can and must the society be satysfied by that? Certanly no. Basic potential for development and progress of any society are young men. We should maximaly posibly support their development and education. To succed at this area we should support the education of the teachers, their social place and inportance. We should let them know we appriciate their hard work. They should be rewarded according to their work and the inportance of that work on the future of all society, and not to force them that in apsence of subjects for life become corrupted as it has happend at most of other areas.

\section{Situational interest for mathematics studying}

Students interest for mathematics and natural sciences is inportant effect to motivation of the student and has also positive effects to studying, understanding of natural-scientific contents. Personal and situational interest creates an optimal conditions for studying. Students interest begins and develops by interaction of the students and enviroment. Enviroment are objects that circumscribe the student or the activities the student is effected by. Student includes in activities if he is interested in topic or effected motivating activities from enviroment. Krapp et al., (1992) introduce two tipes of interest:personal (individual) interest and situational interest. 
Personal interest is individual predisposition according to the contents. Situational interest stimulates with educational activities. It is created by certain actions as exploring work, work on experiment, or concrete objects as an interesting movie, text and similar.

For the difference of personal interest which is relativly constant even when the enviroment is without stimula- tion, situational interest survives as long as the enviroment stimulates it. In the class enviroment situational interest is mostly under the effect of teacher, who can stimulate interest of the students for natural scientific contents in various ways. On the following graph are shown the results of research situational interest at above average and below average mathematicians.

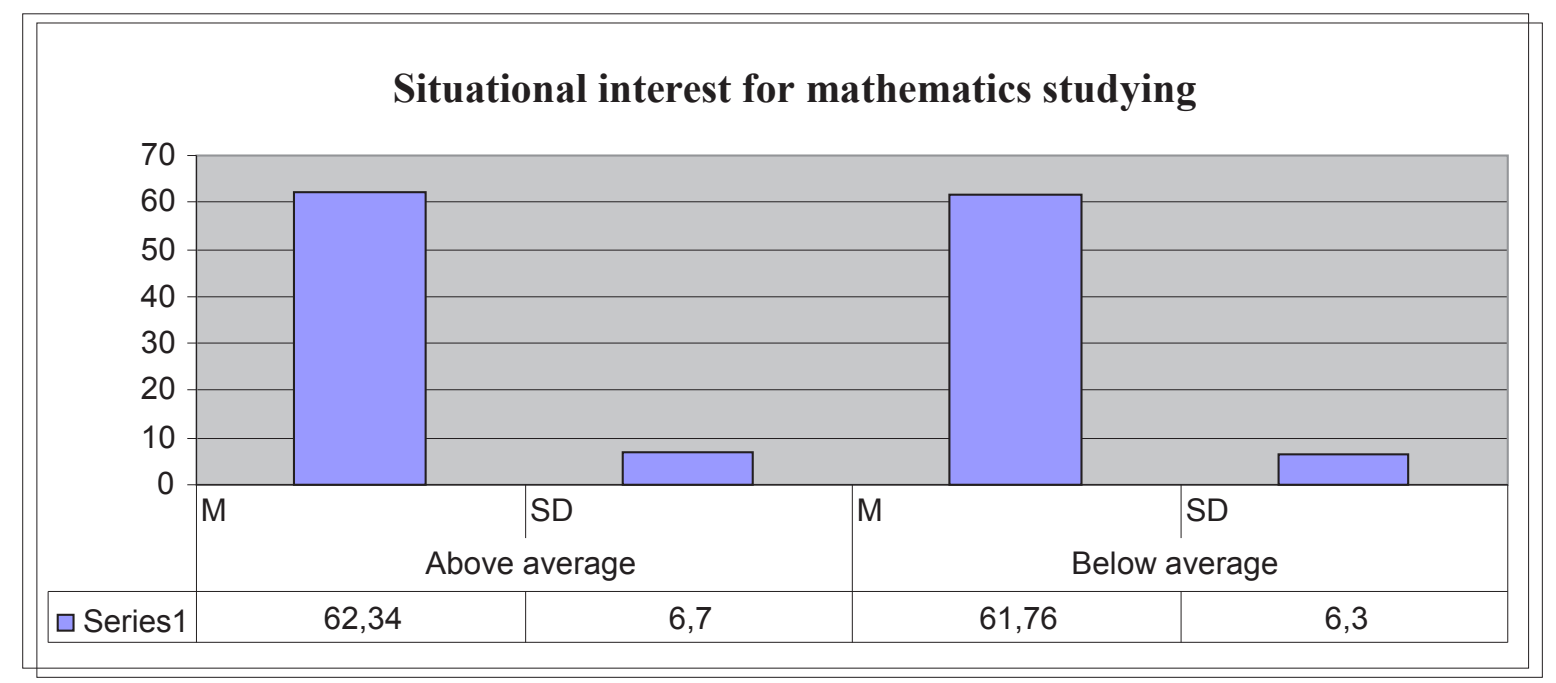

Graph 6. Situational interest for mathematics

On the base of reasearch results variable which also doesnt differ those two groups is a situational interest for mathematics. In other words for both groups of students distinct aspects of studying and teaching at the mathematic lesson are equally interesting even when the topic is solving mathematical problems. Possibly that equal and also very high situational interest for mathematics in both groups of students is a consequence of ability of our teachers to indivizulize the lesson and give a support to any single student.

\section{Atributes ofsucces and unsucces at mathematics}

We analysed attributes of success and unsuccess on the chosen sample of students and we came up with the results shown in the following table.

Table 3. Atribut of success and unsuccess

\begin{tabular}{lcccc}
\hline Variable & Above average & \multicolumn{3}{c}{ Below average } \\
\hline Atributing success & $\mathrm{M}$ & $\mathrm{SD}$ & $\mathrm{M}$ & $\mathrm{SD}$ \\
\hline Ability and personality & 4.05 & .65 & 4.09 & .80 \\
Aktivity and motivation & 3.67 & .77 & 4.1 & .75 \\
Outer factors & 2.78 & 1.03 & .3 & $\mathrm{M}$ \\
\hline Atributing unsuccess & $\mathrm{M}$ & $\mathrm{SD}$ & .97 & $\mathrm{SD}$ \\
\hline Ability and personality & 2.05 & 1.15 & 2.83 & 2.78 \\
Aktivity and motivation & 2.17 & .88 & 2.89 & 1.38 \\
Outer factors & 1.75 & & 1.56 \\
\hline
\end{tabular}

Also the students gifted for mathematics at much more measure then the average students atribute their sucess and unsuccess to outer effects, but also unproper ability and ability of the person mark as less inportant for unsuccess. But those two groups dont differ much at atributing the sucess at mathematics to the inner stable factors, which means abilities of personality. This informations combined with some other reasearches (Weiner, 1985) about development atribution of school sucess at students, in which is comfirmed that the children of youger school age still cannot clearly differ the rols of some inner factors in sucess. Since that in fourth grade most of the student is capable to learn school subjects at the areas of language, nature and society, mathematics is a shool subject at which at that age can survive unsuccess. We hold that this fact can explain high conection of some atributes of unsuccess with discrimination function. On the other side more visible conecting unsuccess to outer reasons at average students could have protecting function, by carring a feeling of personal value at this area. 
But at the same time atributing unsucess abilities of personality could be understod as a source lattter learned helplesnes at the area of mathematics at average students (Weiner, 1985)

\section{CONCLUSION}

On the base of the results of reasearch we can conclude that the hypotesis of reasearch is comfirmed, that the differences at emotional and conactive abilities at ten years old above average mathematicians and their colegues which are below average mathematicians. Above average children undubtly posess a potential for sucess in various activities. But will this potential develop and will the child realy be succesful at certain areas depends of various inner and outer factors. From outer factors most iportant are the effects of enviroment (primary, the family and school), which means to give a chance to the child to show what it can do. From inner factors mostly mentioned are motivation, self anxiety, construction of values etc. (Joswig, 1994). Reasearches show that this factors are responsible not only for the differences in succes between above average and belowe average but also for the differences inside thr group above averages. On the base of ankete students and marks of teachers above average for mathematics are $34.5 \%$ and below average are $65.5 \%$. On the fundament of results of analysis single variables it is confirmed that two groups of students best differ following variables:atribution of succes to motivationand activity, and outer reasons atribution of unsuccess abilities of personality and mathematical anxiety. Above average students show greater interest for school work at the mathematic lessons and greater ability to understand mathematics by themselves, and much easier understand the level of their succes using their own thinking instead of waiting for return informations. Variable which much differs this two groups is fear from mathematics or mathematical anxiety. Data show that the group of above average much less survives uncofortable situations, or emotional reactions while cnfronting the mathematics.

An average students actually make weaker success at mathematics, and for their unsucces mostlyblaim outer factors that cant be controled, and it is logicly that the check of knowledge from mathematics except much harder then the above average. Between the groups is not confirmed the difference in variables, atribution of sucess to abilities of personality, atribution of unsucess to activity and motivation, selfrespect and situational interest for mathematics. Unexistance the difference at atributions could be partialy explained by unsuficcient systematic differing rolls of those factors at mathematical succes at that age. Analysis showed that in conactive variables at this age possible to differ above average and below average mathematicians. The results obtained tell as starting hypotesis of existance of specific construction of motivational corelat manifested giftness which can be rocognized already in young school age. The other relevat evidence tels about that, even an average students at that age posess very good atributial construction, and shown situational interest for mathematics.Since some reasearches tells how during latter school mathematics becomes as very disguasting subject which creates high anxiety and a sense of learned helplesnes,open question about the character and process which leads to such changes. Longitudinal reasearches at the area of mathematical gift show that stimulation through special educational programs of mathematics and natural sciences gets a big advantages to the high ability. On the other side reasearch informations about an advantage at social adaption of above average tells that is stimulating family climate main factor of latter academic and profesional succes of gifted ones.

All of this directs to the need for more exploration of corelats high abilities, especially those at the area of enviromental factors. Those reasearches should show the way to give instrumental, emotional, and social help to the family at the school directed to development of intelectual abilitiesbut also for awekening intrinzic orientation and positive emotions very inportant for realization a gift of child.

\section{REFERENCES}

Arsanagić, Š. (2001) Aspects of math teaching for gifted students. Sarajevo: Association of mathematicians $\mathrm{BiH}$.

Čudina, Obradović M. (1991). Methods and techniques of research in education and training. Zagreb: Školska knjiga.

Joswig, M. (1994). Knowledge-Based Seismogram Processing by Mental Images. IEEE Transactions on Systems Man and Cybernetics 24(3):429-439. doi: 10.1109/21.278992

Koren, I. (1989). How to recognize and identify a gifted students. Zagreb: Školske novine.

Krapp, A. et al., (1992). Konzepte und Forschungsansätze zur Analyse des Zusammenhangs von Interesse, Lernen und Leistung. In A. Krapp, \& M. Prenzel, Interesse, Lernen, Leistung. Neuere Ansätze einer pädagogisch-psychologischen Interessenforschung (pp. 9-52). Münster: Aschendorff.

Weiner, B. (1985). An Attributional Theory of Achievement Motivation and Emotion. Psychological Review, 92, 548-573. 